\title{
Genetic Distance, Economic Growth and Top Income Shares: Evidence from OECD Countries *
}

\section{Anjan K. Saha ${ }^{+}$and Vinod Mishra ${ }^{\#}$}

\section{Abstract:}

The relationship between economic growth and income inequality remains a puzzle in the literature. The main problem has been finding a way to account for the endogeneity of growth. Using century-long data of 14 OECD countries, this study disentangles the growth-inequality relationship. In doing so, our main contribution is employing genetic and geographical distances as instruments for economic growth. The instruments are constructed on the premise that the growth of one country spills over to the others if they are connected through trade and other forms of exchange; however, the genetic and geographical distances between countries represent barriers to such spill overs. Using alternative specifications and measures, we find that growth reduces the inequality measured by top income shares. Another important finding is that the effect of growth on top income shares is more significant among the highest income groups. We also find that growth, by reducing inequality, neutralises the inequality-enhancing nature of capital, hence confirming the prediction of Thomas Piketty regarding the pervasive nature of capital.

Keywords: Genetic distance, top income shares, income inequality, economic growth.

JEL Classification: D31, 011, 015, N10.

\footnotetext{
* The authors would like to thank Professor Jakob Madsen (University of Western Australia), Professor Oded Galor (Brown University), Professor Stelios Michalopoulos (Brown University), Professor Russell Smyth (Monash University) and participants of Warwick Summer Workshop on Economic Growth for their comments and suggestions. We thank Prof. Sushanta Mallick (handling editor) and two anonymous referees, whose useful feedback considerably improved an earlier version of this paper. We are especially thankful to Professor Jakob Madsen (University of Western Australia) for providing some of the data used in this paper.

+ Additional Commissioner of Taxes, National Board of Revenue of Bangladesh. Email: anmon1010@ gmail.com

\# Corresponding Author. Department of Economics, Monash University, Melbourne, VIC - 3800, Australia. Email:

vinod.mishra@monash.edu, Phone: +61 399050038
}

(C) 2020 Anjan K Saha and Vinod Mishra

All rights reserved. No part of this paper may be reproduced in any form, or stored in a retrieval system, without the prior written permission of the author.

monash.edu/ businesseconomics

ABN 12377614012 CRICOS Provider No. 00008C 


\section{Introduction}

The growing inequality in many countries has renewed the discussions about the relationship between economic growth and income inequality (Atkinson et al., 2011; Islam and McGillivray, 2020; Piketty, 2014). Growth affects inequality through many ways, such as redistribution, employment generation and human capital development (Hermansen et al., 2016; Murphy and Topel, 2016). Inequality also affects growth through various channels, such as savings, innovation, fertility, social unrest, public policy and credit market imperfections (Aghion et al., 2019; Agnello et al., 2012; Alesina and Perotti, 1996; Berg et al., 2018; Bourguignon and Scott-Railton, 2015; Gabaix et al., 2016; Gründler and Scheuermeyer, 2018; Kennedy et al., 2017). Moreover, growth and inequality are both affected by some common factors such as the existing level of development, technological development and trade. Growth triggers financial reforms and is a catalyst for a well-functioning financial system that may reduce inequality (Agnello et al., 2012; Baiardi and Morana, 2018).

Jones and Kim (2018), in a Schumpeterian model of top income, theorise that growth increases top income shares and, simultaneously, top income groups exert effort to generate high growth. A massive debate, therefore, exists in the literature on the direction of causality between growth and inequality (Aghion et al., 1999; Bourguignon and Scott-Railton, 2015). Moreover, the growth-inequality relationship remains a puzzle because it varies according to countryspecific, group-specific and period-specific factors (Alvaredo et al., 2018; Hermansen et al., 2016). As a result, disentangling the relationship between growth and inequality and teasing out the unidirectional effect of one on the other is difficult.

Against this backdrop, our aim is to disentangle the growth-inequality relationship by isolating the one-way effect of growth on inequality. To examine the unidirectional impact of growth on inequality, we employ two instruments for economic growth based on the idea that the growth of one country spills over to other countries if they are engaged in trade and other forms 
of economic exchanges. We argue that the extent of spillover is not the same between all countries and that it is inversely related to the geographical and cultural distances between two trading countries.

In a study dating back to 1955 , Simon Kuznets found a non-linear effect of economic development on inequality. He explained it by suggesting that in the early stages of development, poor, unskilled workers earn wages that are significantly lower than those earned by rich, skilled workers. Because of this difference in wages, economic growth initially favours the rich. However, over time, the weaker segment of the population internalises the benefits of development by gradually gathering more skills, experiences and education for themselves and for their offspring and therefore start reaping the benefits of economic growth. As the economy grows, this phenomenon produces an inverted-U pattern on the inequality-growth relationship. Several empirical studies published after the seminal work by Kuznets (1955) tried to empirically validate his conclusions. For instance, Barro (2000) and Chambers (2007) provide empirical snapshots of Kuznets' view by reporting that inequality increases in the short term and declines later. ${ }^{1}$ Anand and Kanbur (1993) and Piketty (2014), however, did not find evidence in favour of Kuznets' hypothesis.

Other traditional theories posit that the higher income of the rich translates into higher levels of investment in productive activities (Kaldor, 1957) or in the human capital development of the rich (Galor and Zeira, 1993). A superior level of physical and human capital directly benefits the rich and helps them to remain at the top of the income distribution (Cingano, 2014; Ostry et al., 2014). The rich also possess the ability to influence the government by impeding the policies that focus on the redistribution of income (Persson and Tabellini, 1994). Moreover, highly disproportionate income distribution may trigger political instability that, in turn,

\footnotetext{
${ }^{1}$ Kuznets' inverted-U relationship is not convincing within a country over time, although it is an appealing premise in a cross-country relationship (Barro, 2000).
} 
jeopardises the investment climate and reduces economic growth (Alesina and Perotti, 1996). Furthermore, in a democratic society, wherein taxation is proportional to income, the poor may vote more favourably towards the income redistribution policies that may discourage investment and lead to reduced economic growth (Persson and Tabellini, 1994).

Despite theories proposing the various channels through which economic growth and inequality are related, the empirical literature remains largely divided on whether the relationship is positive or negative. Lopez (2006) and Chambers (2007), for example, argue that growth is an engine of unequal income distribution. On the contrary, Dollar et al. (2016) find that growth increases the income of the most deprived quintiles in societies and reduces inequality.

The growth literature has recognised the importance of growth spillovers between countries. Growth can create new import demand, result in an outflow of surplus capital and spill knowledge and technologies over to other countries (Ang and Madsen, 2013; Bournakis et al., 2018; Ho et al., 2013). Factor productivity can also spill over to other countries through the cross-border trade of technological products and services (Coe et al., 1997; Guellec and Van Pottelsberghe de la Potterie, 2004; Madsen, 2007). Ho et al. (2013) examine the contribution of bilateral trade to the spillover of economic growth in OECD countries. Ang and Madsen (2013) investigate the possible channels through which spillover may occur, such as trade, foreign direct investment and the geographical distance through which foreign knowledge crosses borders to boost the factor productivity.

In constructing our instruments for economic growth, we use the genetic distance ${ }^{2}$ and capital-to-capital distance ${ }^{3}$ of country pairs as proxies for cultural and geographical distances, respectively. Tinbergen (1962) argues that geographical distance represents a barrier to trade

\footnotetext{
${ }^{2}$ Genetic distance is the elapsed time since the populations of the two countries had a common ancestor.

${ }^{3}$ Capital-to-capital distance refers to the distance between the two capital cities of the country pairs. In this paper, we interchangeably use capital-to-capital distance and geographical distance. The distance is adjusted for the country-pairs contiguity, colonial history and language.
} 
because it increases transportation costs. Spolaore and Wacziarg (2009) argue that genetic distance represents a barrier to the diffusion of development. Guiso et al. (2009) posit that two genetically distant countries share a less common culture, tradition and taste and are less likely to have a high level of trust between them. Lack of trust represents a barrier to trade.

In this study, we measure income inequality using top income shares. Top income data for more than a hundred years is now available from the World Top Income Database of Paris School of Economics. We use the OECD countries' sample between 1900 and 2011 in an unbalanced panel. ${ }^{4}$ The countries considered are Australia, Canada, Denmark, Finland, France, Germany, Japan, the Netherlands, New Zealand, Norway, Sweden, Switzerland, the United Kingdom and the United States. The data are averaged for every three years, starting from 1900. This approach allows us to consider the long-term growth-inequality relationship and reduces the serial correlations in the standard errors. ${ }^{5}$

The existing literature on the relationship between top income shares and economic growth is relatively sparse. In exploring the determinants of top income shares, Roine et al. (2009) find a positive effect of growth on the top $1 \%$ income shares and a negative effect of growth on the top $2 \%-10 \%$ income shares. ${ }^{6}$ Andrews et al. (2011) investigate the reverse relationship of the effect of top income shares on economic growth using the data of 12 developed countries. They use lagged levels of gross domestic product (GDP) per capita to address the endogeneity of economic growth. The study does not find any systematic effect of top income shares on economic growth.

\footnotetext{
${ }^{4}$ The panel is unbalanced because of the missing values of top income data between 1900 and 2010. For instance, the top income data for Switzerland is available only after 1930.

${ }^{5}$ In addition to using the three-year averaged data, we experimented with using the yearly data and five-year averages. However, the key conclusions remain unaffected.

${ }^{6}$ The authors use the data of India, Argentina and 14 OECD countries in an unbalanced panel covering the last century.
} 
Using the two instruments, we consistently find that growth has a negative effect on the various measures of top income shares in OECD countries. ${ }^{7}$ In the second-stage regressions, the estimates provide evidence that the exogenous components of the variations in growth pick up the variations in the top income shares. We also find that capital share (in income) has a positive effect on top income shares. As a result, whereas growth reduces inequality, capital share increases it. The opposite effect of growth and capital share on top income shares reinforces Thomas Piketty's idea that the net value of the difference between the rate of return to capital and rate of economic growth matters in deciding the direction of the inequality.

Our findings are consistent with those of Dollar and Kraay (2002) and Dollar et al. (2016), who find an association between the higher GDP and income growth of the bottom $20 \%$ and $40 \%$ of a population. Our findings are also consistent with those of Jaumotte et al. (2013), who find that growth has a negative effect on the income share of the highest income quintile in contrast to the rest. We, however, do not find any non-linear effect of growth on top income shares, as suggested by Kuznets (1955).

The rest of the paper proceeds as follows: Section 2 describes the data sources, measurement issues, instruments and empirical strategies, Section 3 analyses the results, including two robustness checks, and Section 4 concludes the study.

\section{Data, Measurement and Empirical Framework}

The empirical strategy involves measuring the effect of economic growth on top income shares. We use the following specifications:

$$
\text { Top }_{i t}=\alpha_{i}+\gamma_{t}+\beta \text { Growth } \text { it }+\delta^{\prime} C V_{i t}+\varepsilon_{i t}
$$

where Growth refers to per capita GDP growth and Top refers to top income shares. $\beta$ is the parameter of interest, $C V$ is the vector of control variables and $\varepsilon$ is the error term.

\footnotetext{
${ }^{7}$ Roine et al. (2009), however, find both positive and negative effects of growth on various top income groups.
} 
A third variable may possibly have a strong influence both on economic growth and top income shares. Barro (2000) explicitly emphasises the need to control for the level of economic development because it captures the country-specific policy variables that cannot directly be measured in the regression. ${ }^{8} \mathrm{We}$ also control for several other variables that are standard to control for when examining the inequality-growth relationship and for which data are available for the entire last century. The variables are educational attainment, investment, imports, the extent of domestic patent applications, bank assets, capital shares in income and top marginal tax rates. Top marginal tax rates are believed to be highly associated with inequality reduction (Shin, 2012).

In Eq. (1), measuring the true effect of growth on top income shares is difficult because Growth and $\varepsilon$ can be correlated. Therefore, we estimate $\beta$ using the instrumental variable (IV) estimators. The first stage of regression is as follows:

$$
\text { Growth }_{i t}=a_{i}+\mu_{t}+\theta I V_{i t}+\varphi^{\prime} C V_{i t}+e_{i t}
$$

IV is measured by the one-period-lagged weighted growth of other countries. The weights are calculated using the genetic and geographical distances between the country pairs.

It is realistic to assume that the growth of one country cannot instantaneously transmit its effects to other countries because trade requires some time to take place. For instance, a gap exists between income and a purchase decision taken by households and firms. A time gap also exists between opening a letter-of-credit and delivering the imports in the hands of the buyers. Based on this period gap, we use the one-period-lagged weighted growth of other countries as an instrument for economic growth.

\subsection{Construction of the instruments and addressing causality}

\footnotetext{
${ }^{8}$ Moreover, the level of development is essential to check for income convergence across the countries and for the redistribution capacity of the economy (Sigelman and Simpson, 1977).
} 
Genetic traits are mainly vertically transmitted. Inertia is always present in the horizontal transmission of genetic traits. Genetic distance is a measure of this inertia in the horizontal transmission across populations. It refers to the elapsed time since the populations of two countries had a common ancestor. Spolaore and Wacziarg (2009) argue that genetic distance prevents the diffusion of development across genetically different populations. Further extending the idea, Spolaore and Wacziarg (2013) argue that genealogical links (lower genetic distance) between populations facilitate the transmission of development. Guiso et al. (2009) contend that country pairs with greater genetic proximity are more likely to trade.

Geographical proximity, on the contrary, reduces transportation costs and facilitates the diffusion of development through trade. It also has a favourable effect on productivity spillovers through product and labour market channels (Mankiw et al., 1992; Molnár et al., 2008). Nearness to major markets, which is captured by proximity, plays an influential role in determining the growth per capita of a country. Moreover, geographical proximity ensures easy access to nearby markets and reinforces competition among producers. It encourages innovation and efficiency in the use of resources.

We construct growth spillover through genetic proximity (GSGP) and growth spillover through geographical (physical) proximity (GSPP) as instruments for economic growth. The premise is that the diffusion of growth is more likely to occur when two countries are in closer genetic or geographical proximity (or when the genetic or geographical distance between them is small). ${ }^{9}$

Suppose country $\mathrm{j}$ is at a distance of $\mathrm{d}_{\mathrm{j}}\left(\mathrm{d}_{\mathrm{j}}=\right.$ genetic or geographical distance $)$ from country $i$. The inverse of the distance $\left(1 / d_{j}\right)$ captures the nearness or proximity of country $j$ to

\footnotetext{
${ }^{9}$ GSGP (GSPP) refers to the one-period-lagged weighted average growth of other countries obtained using the genetic (geographical) proximity between a country and its trading partners as the weight. This weight is the inverse of genetic (geographical) distance, the data for which is obtained from Spolaore and Wacziarg (2009) and Mayer and Zignago (2011).
} 
country $i$. The nearer country $j$ is to country $i$, the more influence its growth has on the growth of country $\mathrm{i}$ because it increases the cultural similarity and reduces the transaction costs of the diffusion of growth. This condition is expressed as follows:

$$
I V_{i t}=\frac{\sum_{1}^{n-1}\left(\frac{1}{d_{j}}\right) * \text { Growth }_{j t-1}}{\sum_{1}^{n-1}\left(\frac{1}{d_{j}}\right)}, \quad(j \neq i)
$$

where IV = GSPP or GSGP, depending on $d_{j}$. The inverse of distance is used as a weight and quantifies how close country $\mathrm{j}$ is to country $\mathrm{i}$ in terms of genetic or geographical distance. To construct $I V_{i t}$, we use the one-period-lagged values of growth of other countries $\left(\right.$ Growth $\left._{j t-1}\right)$ by assuming that one period is required for growth to spill over from one country to the other through trade and other channels of exchange. By construction, the instrument is the previous period's weighted growth of other countries.

The use of the previous period's weighted growth of the other countries as an instrument overcomes reverse causality because the growth of the country of measurement cannot affect the previous period's growth. The instrument also cannot directly affect top income shares because the growth of the other countries affects top income shares not directly but through the channel of the economic growth of the country of measurement. Thus, the use of the one-period-lagged weighted growth of other countries as an instrument reduces the possibility of simultaneity that may run from the primary explanatory variable to the instruments. ${ }^{10}$

\section{[Place Figure 1 here]}

Figure 1 illustrates the relationship between income growth per capita and the two instruments, GSGP and GSPP. The lagged genetic and geographical proximity weighted growth of other countries seems to have a positive relationship with the GDP per capita growth. We

\footnotetext{
${ }^{10}$ Although using one-period-lagged growth may not be an entirely convincing way to address the simultaneity between growth and top income shares, the one-period-lagged measure of growth of other countries can remedy the problem, given the scarcity of a good external instrument of economic growth in the existing literature, especially in a panel of countries.
} 
construct GSGP and GSPP for 19 OECD countries for which genetic distance data are available. ${ }^{11}$

Although we find a relatively high correlation between genetic and geographical distance (0.69) in our dataset, we include both the variables in the analysis because they measure different factors influencing economic growth and development. The geographical distance measures the economic cost associated with trade between the two countries in the form of transportation costs. The genetic distance (a proxy for cultural distance), on the contrary, represents a barrier to growth spillover because genetically similar countries tend to engage more in trade. Moreover, our dataset includes country pairs that are genetically proximate (for instance, the UK and Australia) but physically distant.

\subsection{Data Sources and Measurement Issue}

We used the before-tax top income data of the 14 OECD countries drawn from their tax databases. We measure the averages of data from three consecutive years since 1900. The year averaging reduces the missing data problem to a great extent because we average only the available data points within every three years. This also reduces the number of data observations; however, the effect of business cycle fluctuations on the variables is minimised.

\section{[Place Figure 2 here]}

Figure 2 shows the variation of the top $1 \%$ income shares with economic growth in broadly characterised countries: (a) Nordic versus non-Nordic countries and (b) European versus non-European countries. Nordic countries are regarded as high redistribution countries with high marginal tax rates. We want to ensure that the European countries, as opposed to their nonEuropean counterparts, are not driving our test results. In all the groups, the association between

\footnotetext{
${ }^{11}$ In addition to the 14 OECD countries for which the growth-top income shares relationship is established, the other countries included in the GSPP and GSGP construction are Austria, Belgium, Spain, Italy and Portugal.
} 
the top $1 \%$ income shares and growth seems to be negative. However, as long as the relationship between top income shares and economic growth suffers from a severe endogeneity problem, concluding the status of the relationship based only on Figure 2 is challenging. In this context, the IV regression results in section 3 can provide more specific inferences.

Throughout the study, the top $1 \%$ income shares are used as the primary measure of income inequality. To check the robustness of the results, other top income measures such as the top $10 \%$, top $5 \%$, top $0.5 \%$ and top $0.1 \%$ are also used. We use the growth data from the Maddison Project Database, which provides an extension of the data from Maddison (2006) up to recent years. The control variables of educational attainment, capital-output ratio, number of domestic patent applications, imports and initial GDP per capita are essential because they have a relationship with both top income shares and economic growth. For example, educational attainment is generally regarded as a source of inequality reduction because public education may narrow down the gap between the rich and the poor (Barro, 2000; Galor and Zeira, 1993).

The description of the variables and the data sources are provided in Table 1 . The correlation coefficients and the summary statistics of the key variables are presented in Appendix Tables A1 and A2, respectively.

\section{[Place Table 1 here]}

We measure genetic distance by employing Spolaore and Wacziarg's (2009) country-pair dataset. The dataset is based on the seminal work by Cavalli-Sforza et al. (1996). They divide the world population into 42 main population groups with 45 gene types (along with their 128 allele versions). ${ }^{12}$ Each population group has a high level of genetic similarity and is distinct from the other groups. Given that a country may comprise a heterogeneous population from various

\footnotetext{
${ }^{12}$ Genes are the sequences of the protein encoded in deoxyribose nucleic acids (DNA). A gene in a particular locus of a chromosome in a cell is found to have multiple versions, which are known as alleles. New alleles evolve through natural selection because of the exposure of a population group to a new environment for an extended period.
} 
genetic backgrounds, Spolaore and Wacziarg (2009) calculate each country's weighted allelic frequency from the fractions of the main genetic population groups. ${ }^{13}$

\section{Results}

\subsection{The effect of growth on the top $1 \%$ income shares}

Panel A of Table 2 reports the results of the basic model in Eq. (1) that measures the effect of economic growth on the top $1 \%$ income shares. Column (1) presents the univariate least square regression results, in which growth has a highly significant negative relationship with the top $1 \%$ income shares. The results show that economic growth reduces inequality by decreasing top income shares. However, we cannot rely on these results because the univariate regression explains only $1.2 \%$ of the variations in the dependent variable.

For explaining income inequality, including the initial income level is vital because it determines the level of development, which ultimately determines how the benefit of growth will be redistributed in a society. For example, Sigelman and Simpson (1977) argue that, compared with poor economies, low-income earners are more patient in prosperous economies because a higher amount of surplus remains available for redistribution. Therefore, we include the initial GDP per capita in the regression in column (2). The results show that the inclusion of the GDP per capita increases the explanatory power of the regressions up to $40 \%$ compared with only $1.2 \%$ in column (1).

\section{[Place Table 2 here]}

\footnotetext{
${ }^{13}$ These data exclude the genetic influence on the phenotypic variation, which directly affects survival and fitness. Instead, the data include only the selectively neutral allele frequency of a population group that is free from phenotypic variations through selective pressure, as suggested by Darwin, appropriate for the reconstruction of evolutionary history. Based on Cavalli-Sforza et al.'s (1994) measurement, the genetic distance is the highest between Papua New Guineans and Mbuti Pygmies (0.4573) and the lowest between the English and Danish (0.0021).
} 
Columns (3)-(7) report the effect of growth on the top $1 \%$ income shares based on the IV regressions. The regression results throughout columns (3)-(5) in panel A show a highly significant negative effect of growth on the top $1 \%$ income shares. The magnitudes of all the IV regression results in columns (3), (4) and (5) seem to be much higher than those of the OLS results in columns (1) and (2). In columns (3) and (4), GSGP and GSPP are used as instruments for growth, respectively, and in column (5), the two instruments are combined. We run separate estimates using each instrument to ensure that the high correlation between genetic proximity and geographical proximity is not driving the results. We see that the coefficients of growth and other explanatory variables qualitatively remain the same in all three specifications, which suggests that the high correlation between the two variables is not a problem. Moreover, the chisquare p-value (0.21) of Hansen's J-statistic in column (5) provides strong support in the overidentification of the basic model.

In column (6), GSGP is included as a control variable in the second stage, and GSPP is the excluded instrument for growth. By contrast, in column (7), GSGP is the excluded instrument for growth and GSPP is included as an explanatory variable in the second stage regression. The inclusion of GSGP and GSPP in columns (6) and (7), respectively, as the right-hand-side variables in the second stage, puts forward a simple exclusion restriction strategy. The strategy is based on the premise that once the variation of the dependent variable is captured through the instrumentation of the primary explanatory variable, an instrument added as a control variable in the second stage cannot have any significant effect on the dependent variable. That is, the added instrument will only work through the primary explanatory variable (for a similar strategy, see Acemoglu et al., 2001; Madsen and Ang, 2016). Therefore, the insignificance of the coefficient measures of GSGP and GSPP in columns (6) and (7), respectively, of panel A extends additional support to the validity of the basic model in Eq. (1). 
Columns (3)-(7) in panel B report the first-stage results of the IV regressions in panel A. Because income converges across countries, inclusion of the income level in any growth regression is essential. The coefficient of the initial GDP per capita is insignificant in each regression. This indicates that the effect of the initial GDP per capita affects growth only through the channel of the instruments for growth. In column (3) and (4), GSGP and GSPP are used, respectively, as instruments for economic growth. They are significant at the $1 \%$ level in both cases, confirming the strength of both instruments. In the following column, when the two instruments are combined, the coefficients of GSPP are significant at the $1 \%$ level, which underlines the validity of the used instruments.

The first-stage $\mathrm{R}^{2}$ value and the high chi-square p-value of Hansen's $\mathrm{J}$ statistic $(0.21)$ in column (5) provide strong support to our model. Moreover, the first-stage F-statistics of the excluded instrument (21.0) in column (5) is more than double the rule of thumb of 10 proposed by Staiger and Stock (1997), providing confidence that the instruments are reliable and valid. We use the model in column (5) as the benchmark model for the subsequent analysis. The benchmark model reports that a one-percentage-point increase in the GDP per capita growth reduces the top $1 \%$ income shares by $1.8 \%$. In other words, a one-standard-deviation increase in growth can reduce the top $1 \%$ income shares by $40 \%$ of its standard deviation.

\subsection{Robustness check using alternative measures of top income shares and alternative samples}

The above findings are based on the underlying assumption that economic growth negatively affects top income shares. However, until now, only the top $1 \%$ income shares have been used for evaluation. The first four columns of Table 3 present the estimates of the effect of growth on many other top income shares. Columns (5) and (6) present the estimates excluding those of the non-European and Nordic countries from the sample. The IV regression results of the effect of top income shares on economic growth using GSGP and GSPP together as 
instruments for growth are reported. Irrespective of the measures of the top income groups or the subsamples of the countries, growth seems to have a highly significant negative effect on top income shares. Another interesting finding is that the effect of growth on top income shares is the strongest among the highest income groups. The results in the first four columns are consistent with the idea that growth is beneficial for the poor (Dollar and Kraay, 2002).

\section{[Place Table 3 here]}

\subsection{Alternative model specifications with additional controls}

The analysis of the effect of growth on top income shares in the above discussions is based on the basic model in Eq. (1). In this section, the basic model is estimated with additional control variables. This approach provides us with the opportunity to examine the effect of capital share (in income) and top marginal tax rates on top income shares to verify whether our conclusions are per Piketty's (2014) hypothesis. In particular, we examine whether higher capital income shares or higher top marginal tax rates have any direct effect on top income shares other than through the channel of economic growth, as Piketty advocates in favour of a global tax rate across countries to control the pace of increasing income inequality in the coming decades.

\section{[Place Table 4 here]}

In Table 4, we separately introduce educational attainment, import value, total investment, number of domestic patent applications, ${ }^{14}$ bank deposits, capital share (in income) and top marginal tax rate into the regressions. The effect of growth on the top $1 \%$ income shares provides similar results irrespective of the control variables used. The results are at the $1 \%$ level of significance, and the magnitudes seem to be mostly the same across the specifications. The

\footnotetext{
${ }^{14}$ One of the anonymous reviewers pointed out that patents are not very representative of the R\&D activity of many industries in the economy; hence, we also used R\&D intensity (defined as the share of R\&D investment in total investment) in place of patents in Table 4 as an alternative measure. However, the results were qualitatively the same. Hence, we do not report them in the paper.
} 
analysis in this section reinforces that economic growth has a negative effect on top income shares, regardless of the control variables used.

In columns (1)-(7), the control variables are used one at a time, and they are combined in columns (8) and (9). Throughout the columns, initial GDP per capita, GDP per capita growth, total investment and top marginal tax rates are inversely related to the top $1 \%$ income shares. By contrast, capital share (in income), bank deposits, technological development and imports are positively related to the same.

The results in columns (6), (7) and (9) provide a check for the sensitivity of our results with Piketty's view on the future of top income shares. ${ }^{15}$ The findings are consistent with Piketty's (Piketty, 2014) idea that the rise in capital income increases top income shares, whereas economic growth and progressive taxation downsize it. According to the results reported in column (9), a one-standard-deviation increase in capital shares increases the top $1 \%$ income shares by $37 \%$ of its standard deviation, which is $\sim 3.3 \%$ increase in the top $1 \%$ income shares.

Conversely, a one-standard-deviation increase in the top marginal tax rates reduces the top $1 \%$ income shares by $24 \%$ of its standard deviation, which is $\sim 2.1 \%$ decrease in the top $1 \%$ income shares. Moreover, a one-standard-deviation increase in growth is associated with a reduction of the top $1 \%$ income shares by $41 \%$ of its standard deviation, which is around $3.6 \%$. Therefore, the difference between return to capital (r) and economic growth (g), as Piketty argues, can be the driving force to dictate the future accumulation of wealth because the two have opposite effects on top income shares. Although the signs of the effects of return to capital, economic growth and top marginal tax rates on top income shares are in accordance with Piketty (2014), we cannot directly compare our results with those of Piketty because of the lack of data, specifically of the return to capital for all the countries in the last century.

\footnotetext{
15 The top marginal tax rate data are not available for Norway, the Netherlands and Switzerland. For Finland, the number of observations is small.
} 
Piketty suggests progressive taxation as a remedy for the widening income gaps. Our results also confirm that top marginal tax rates have a significant adverse effect on before-tax top income shares. This situation is plausible because progressive taxation can reduce the work efforts of the rich. Although an extensive examination of the effect of increasing tax rates on top income shares is beyond the scope of this work, it can be a topic for future study.

\subsection{Testing the non-linearity between growth and top income shares}

Table 5 expands the model in Eq. (1) with the square of growth per capita as an additional control variable to test whether growth has a non-linear effect on top income shares. We use growth and squared growth with the instruments based on the assumption that if the growth of other countries captures the variation in top income shares by realising the variations in growth, then their squares will work in a similar manner. The coefficients of growth per capita do not seem to be significantly different from the results of the benchmark regression with the top $1 \%$ income shares. The coefficients of squared growth per capita are insignificant across the top income groups. The results indicate that top income shares are not non-linear (quadratic) in the growth per capita over the last century.

\section{[Place Table 5 here]}

\section{Conclusions}

No consensus has been reached in the literature on the effect of economic growth on income equality. We revisit this old but unresolved issue for a panel of 14 OECD countries for which data are available since the beginning of the twentieth century. We employ two instruments for economic growth, which are novel in our context, and discover that growth reduces top income shares, irrespective of the size of the top income groups. Our main contribution in this paper is the use of the new instruments and the resolution of the reverse causality problem. 
The two instruments are constructed on the basis of the simple premise that the growth of one country is influenced by the growth of the others, provided that they are connected through international trade and other exchanges. We argue that growth cannot instantaneously spill over from one country to another. A time gap always exists between having an income and making a purchase decision. A transaction cost is also present in terms of time in the international exchange process. For instance, time is required between the shipping of goods from a country and the goods reaching in the hands of the consumers in another country.

Based on this idea, we use one-period-lagged growth of other countries as an instrument for economic growth. The use of a one-period-lagged measure of growth in other countries restricts the possibility of a feedback effect that may run from the country of measurement to the other countries.

We also consider the other transaction costs related to cultural and geographical barriers. The genetic and geographical proximities (the inverse of genetic and geographical distances) of the country pairs in the exchange process are used to calculate the weighted growth of other countries.

The IV regressions show that growth has a highly significant negative effect on top income shares. The results are consistent with those of Kuznets that growth generally reduces income inequality in the long run. Our benchmark result finds a $1.8 \%$ decrease in the top $1 \%$ income shares owing to a one-percentage-point increase in economic growth. This study has another interesting finding in that the effect of growth on top income shares is more significant among the highest income groups. We, however, do not find an inverted-U-shaped non-linearity in the relationship.

Our research reinforces the argument of Thomas Piketty in his influential book Capital in the Twenty-First Century that top income shares increase because of an increase in the capital share in income. We also confirm that the effects of economic growth and capital share on top 
income shares work in opposite directions. Whereas the capital share of income increases the top income shares, growth reduces it. This study, however, does not explore to what extent they neutralise each other because this question is beyond the scope of this study.

Moreover, we find that top marginal tax rates have a negative effect on top income shares. This finding also reinforces Thomas Piketty's argument in favour of using progressive taxation to control the increase in the accumulation of wealth in the hands of the rich. 


\section{References}

Acemoglu, D., Johnson, S., Robinson, J.A., 2001. The colonial origins of comparative development: An empirical investigation. Am. Econ. Rev. 91(5), 1369-1401. https://doi.org/10.1257/aer.91.5.1369.

Aghion, P., Akcigit, U., Bergeaud, A., Blundell, R., Hemous, D., 2019. Innovation and top income inequality. Rev. Econ. Stud. 86(1), 1-45. https://doi.org/10.1093/restud/rdy027.

Aghion, P., Caroli, E., García-Peñalosa, C., 1999. Inequality and economic growth: The perspective of the new growth theories. J. Econ. Lit. 37(4), 1615 - 16660. https://doi.org/10.1257/jel.37.4.1615.

Agnello, L., Mallick, S.K., Sousa, R.M., 2012. Financial reforms and income inequality. Econ. Lett. 116(3), 583-587. https://doi.org/10.1016/j.econlet.2012.06.005.

Alesina, A., Perotti, R., 1996. Income distribution, political instability, and investment. Eur. Econ. Rev. 40(6), 1203-1228.

Alvaredo, F., Chancel, L., Piketty, T., Saez, E., Zucman, G., 2018. The elephant curve of global inequality and growth. AEA Pap. Proc. 108, 103-108.

https://doi.org/10.1257/pandp.20181073.

Anand, S., Kanbur, S.M.R., 1993. Inequality and development: A critique. J. Dev. Econ. 41(1), $19-43$.

Andrews, D., Christopher, J., Leigh, A., 2011. Do rising top incomes lift all boats? B.E. J. Econ. Anal. Policy. 11(1), 1-45.

Ang, J.B., Madsen, J.B., 2013. International R and D spillovers and productivity trends in the Asian miracle economies. Econ. Inq. 51(2), 1523-1541. https://doi.org/10.1111/j.14657295.2012.00488.x.

Atkinson, A.B., Piketty, T., Saez, E., 2011. Top incomes in the long run of history. J. Econ. Lit. 49(1), 3 - 71. https://doi.org/10.1257/jel.49.1.3.

Baiardi, D., Morana, C., 2018. Financial development and income distribution inequality in the euro area. Econ. Model. 70(November 2017), 40-55. https://doi.org/10.1016/j.econmod.2017.10.008.

Barro, J.R., 2000. Inequality and growth in a panel of countries. J. Econ. Growth. 5(1), 5-32.

Berg, A., Ostry, J.D., Tsangarides, C.G., Yakhshilikov, Y., 2018. Redistribution, inequality, and growth: new evidence. J. Econ. Growth. 23(3), 259-305. https://doi.org/10.1007/s10887017-9150-2.

Bourguignon, F., Scott-Railton, T., 2015. The Globalization of Inequality. Princeton University Press.

Bournakis, I., Christopoulos, D., Mallick, S., 2018. Knowledge spillovers and output per worker: An industry-level analysis for OECD countries. Econ. Inq. 56(2), 1028-1046. 
https://doi.org/10.1111/ecin.12458.

Cavalli-Sforza, L.L., Menozzi, P., Piazza, A., 1996. The history and geography of human gene (Abridged paperback edition). J. R. Anthropol. Inst. 2(1), 413.

Chambers, D., 2007. Trading places: Does past growth impact inequality? J. Dev. Econ. 82(1), 257-266.

Cingano, F., 2014. Trends in income inequality and its impact on economic growth. OECD Social, Employment and Migration Working Papers, No. 163, OECD Publishing, Paris. https://doi.org/10.1787/5jxrjncwxv6j-en.

Coe, D.T., Helpman, E., Hoffmaister, A.W., 1997. North-South R\&D spillovers. Econ. J. 107(440), 134-149.

Dollar, D., Kleineberg, T., Kraay, A., 2016. Growth still is good for the poor. Eur. Econ. Rev. 81, 68-85. https://doi.org/10.1016/j.euroecorev.2015.05.008.

Dollar, D., Kraay, A., 2002. Growth is good for the poor. J. Econ. Growth. 7(3), 195-225. https://doi.org/10.1023/A:1020139631000.

Gabaix, X., Lasry, J.-M., Lions, P.-L., Moll, B., 2016. The dynamics of inequality. Econometrica. 84(6), 2071-2111. https://doi.org/10.3982/ecta13569.

Galor, O., Zeira, J., 1993. Income distribution and macroeconomics. Rev. Econ. Stud. 60(1), 35. https://doi.org/10.2307/2297811.

Gründler, K., Scheuermeyer, P., 2018. Growth effects of inequality and redistribution: What are the transmission channels? J. Macroecon. 55, 293-313.

https://doi.org/10.1016/j.jmacro.2017.12.001.

Guellec, D., Van Pottelsberghe de la Potterie, B., 2004. From R\&D to productivity growth: Do the institutional settings and the source of funds of R\&D matter? Oxford B. Econ. Stat. 66(3), 353-378. https://doi.org/10.1111/j.1468-0084.2004.00083.x.

Guiso, L., Sapienza, P., Zingales, L., 2009. Cultural biases in economic exchange. Q. J. Econ. 124(3), 1095-1131. https://doi.org/10.1162/qjec.2009.124.3.1095.

Hermansen, M., Ruiz, N., Causa, O., 2016. OECD iLibrary | The distribution of the growth dividends. Economic Department Working Paper. 1343.

Ho, C.Y., Wang, W., Yu, J., 2013. Growth spillover through trade: A spatial dynamic panel data approach. Econ. Lett. 120(3), 450-453. https://doi.org/10.1016/j.econlet.2013.05.027.

Islam, M.R., McGillivray, M., 2020. Wealth inequality, governance and economic growth. Econ. Model. 88, 1-13. https://doi.org/https://doi.org/10.1016/j.econmod.2019.06.017.

Jaumotte, F., Lall, S., Papageorgiou, C., 2013. Rising income inequality: Technology, or trade and financial globalization? IMF Econ. Rev. 61(2), 271-309.

https://doi.org/10.1057/imfer.2013.7. 
Jones, C.I., Kim, J., 2018. A schumpeterian model of top income inequality. J. Political Econ. 126(5), 1785-1826. https://doi.org/10.1086/699190.

Kaldor, N., 1957. A model of economic growth. Econ. J. 67(268), 591. https://doi.org/10.2307/2227704.

Kennedy, T., Smyth, R., Valadkhani, A., Chen, G., 2017. Does income inequality hinder economic growth? New evidence using Australian taxation statistics. Econ. Model. 65(April), 119-128. https://doi.org/10.1016/j.econmod.2017.05.012.

Kuznets, S., 1955. Economic growth and income inequality. Am. Econ. Rev. 45(1), $1-28$ https://doi.org/10.2307/1811581.

Lopez, H., 2006. Growth and inequality: Are the 1990s different? Econ. Lett. 93(1), 18-25.

Maddison, A., 2006. The World Economy Volume 1: A Millennial Perspective \& Volume 2: Historical Statistics. OECD Development Centre.

Madsen, J.B., 2007. Technology spillover through trade and TFP convergence: 135 years of evidence for the OECD countries. J. Int. Econ. 72(2), 464-480.

Madsen, J.B., 2014. Human capital and the world technology frontier. Rev. Econ. Stat. 96(4), 676-692. https://doi.org/10.1162/REST_a_00381.

Madsen, J.B., Ang, J.B., 2016. Finance-LED growth in the OECD since the nineteenth century: How does financial development transmit to growth? Rev. Econ. Stat. 98(3), 552-572. https://doi.org/10.1162/REST_a_00513.

Mankiw, N.G., Romer, D., Weil, D.N., 1992. A contribution to the empirics of economic growth. Q. J. Econ. 107(2), 407-437. https://doi.org/10.2307/2118477.

Mayer, T., Zignago, S., 2011. Notes on CEPII's distances measures: The GeoDist database (December 1, 2011). CEPII Working Paper No. 2011-25. http://dx.doi.org/10.2139/ssrn.1994531

Molnár, M., Boulhol, H., de Serres, A., 2008. The contribution of economic geography to GDP per capita. OECD Journal: Econ. Stud. 2008(1), 1-37. https://doi.org/10.1787/eco_studiesv2008-art9-en.

Murphy, K.M., Topel, R.H., 2016. Human capital investment, inequality, and economic growth. J. Labor Econ. 34(S2), S199-S127. https://doi.org/10.1086/683779.

Ostry, J.D., Berg, A., Tsangarides, C.G., 2014. Redistribution, inequality, and growth. International Monetary Fund.

Persson, T., Tabellini, G., 1994. Is inequality harmful for growth? Am. Econ. Rev. 84(3), 600621.

Piketty, T., 2014. Capital in the Twenty-first Century. Harvard University Press. Cambridge 
Massachusetts.

Richerson, P.J., Boyd, R., 2005. Not by Genes Alone: How Culture Transformed Human Evolution. University of Chicago Press. Chicago.

Roine, J., Vlachos, J., Waldenström, D., 2009. The long-run determinants of inequality: What can we learn from top income data? J. Public Econ. 93(7-8), 974-988.

Shin, I., 2012. Income inequality and economic growth. Econ. Model. 29(5), 2049-2057. https://doi.org/10.1016/j.econmod.2012.02.011.

Sigelman, L., Simpson, M., Sigelman, L., Simpson, M., 1977. A cross-national test of the linkage between economic inequality and political violence. J. Confl. Res. 21(1), 105-128.

Spolaore, E., Wacziarg, R., 2009. The diffusion of development. Q. J. Econ. 124(2), 469-529. https://doi.org/10.1162/qjec.2009.124.2.469.

Spolaore, E., Wacziarg, R., 2013. How deep are the roots of economic development? J. Econ. Lit. 51(2), 325-369. https://doi.org/10.1257/jel.51.2.325.

Staiger, D., Stock, J.H., 1997. Instrumental variables regression with weak instruments. Econometrica. 65(3), 557. https://doi.org/10.2307/2171753.

Tinbergen, J., 1962. Shaping the World Economy: Suggestions for an International Economic Policy. The Twentieth Century Fund (Vol. 46). Oxford University Press. New York https://doi.org/10.2307/1236502. 


\section{Tables and Figures}

\section{Table 1}

The description of the variables and the data sources.

\begin{tabular}{ll}
\hline Variable & Description \\
\hline Top income shares & $\begin{array}{l}\text { Data was downloaded from the World Top } \\
\text { Income Database of Paris School of Economics. } \\
\text { The data are derived from the tax returns of } \\
\text { countries. They are before-tax data and are in \% } \\
\text { share. }\end{array}$ \\
Initial GDP per & $\begin{array}{l}\text { Initial GDP per capita refers to the GDP per } \\
\text { capita of the earlier period in 1990. }\end{array}$ \\
capita & $\begin{array}{l}\text { International or Geary-Khamis dollars, from the } \\
\text { Maddison Project Database. }\end{array}$ \\
GDP per capita & $\begin{array}{l}\text { Derived from GDP per capita in 1990. } \\
\text { growth }\end{array}$ \\
$\begin{array}{l}\text { International or Geary-Khamis dollars, from the } \\
\text { Maddison Project Database. }\end{array}$ \\
$\begin{array}{l}\text { The distance between two capital cities of a } \\
\text { distance }\end{array}$ \\
$\begin{array}{l}\text { country pair in kilometres. It is measured } \\
\text { following the great circle approach that uses a } \\
\text { longitudinal and latitudinal position of the } \\
\text { capital cities of the countries. The distance is } \\
\text { adjusted for the country-pairs contiguity, } \\
\text { colonial history and language. } \\
\text { http://www.cepii.fr/anglaisgraph/bdd/distances. }\end{array}$ \\
htm
\end{tabular}

Genetic distance Genetic distance between two populations measures the time elapsed between them since they had a common ancestor, where the difference in allele frequency proxies for the elapsed time.

Growth spillover through geographical proximity (GSPP)

Growth spillover through genetic proximity (GSGP)

Educational attainment

Capital share in GDP
Growth spillover through geographical proximity (GSPP) is defined as, $I V_{i t}=$ $\left[\sum_{1}^{n-1}\left(\frac{1}{d_{j}}\right) *\right.$ Growth $\left._{j t}\right] / \sum_{1}^{n-1} \quad\left(\frac{1}{d_{j}}\right)$, where $d_{j}$ is the geographical distance of country $\mathrm{j}$ from country $i$.

Growth spillover through genetic proximity (GSGP) is defined as, $I V_{i t}=\left[\sum_{1}^{n-1} \quad\left(\frac{1}{d_{j}}\right) *\right.$ Growth $\left._{j t}\right] / \sum_{1}^{n-1}\left(\frac{1}{d_{j}}\right)$, where $d_{j}$ is the genetic distance of country j from country $i$.

Educational attainment is the average years of education completed.

Capital share refers to the share of all income other than the labour income share in GDP.
The Maddison-Project, www.ggdc.net

The Maddison-Project, www.ggdc.net

Mayer and Zignago (2011)

Spolaore and Wacziarg (2009)

Details of the construction of GSPP are provided in Section 3.

Details of the construction of GSGP are provided in Section 3.

Madsen (2007) 


$\begin{array}{lll}\text { Import } & \text { Import as a percentage of GDP. }{ }^{16} & \text { Madsen and Ang (2016) } \\ \text { Investment } & \begin{array}{l}\text { Investment as a percentage of total capital } \\ \text { stock. }\end{array} & \text { Madsen and Ang (2016) } \\ \text { Bank assets } & \text { Bank assets as percentage of GDP. } & \text { Madsen and Ang (2016) }\end{array}$

Top marginal tax These are statutory top tax rates of a country. Roine et al. (2009) rates For the UK and the USA, we use the tax rates applicable to incomes higher than five times the GDP per capita, following Roine et al. (2009). Domestic Patent Number of domestic patent applications. Madsen (2007) Applications (logs)

${ }^{16}$ Export data is not available for many countries in the early decades of the last century. Hence, the importGDP ratio is used as a proxy for openness. 
Table 2

The effect of growth on the top $1 \%$ income shares.

\begin{tabular}{|c|c|c|c|c|c|c|c|}
\hline $\begin{array}{l}\text { Dep. variable: Top } \\
1 \% \text { income shares }\end{array}$ & (1) & (2) & (3) & (4) & (5) & (6) & (7) \\
\hline \multirow[b]{3}{*}{ IVs (excluded) } & & & \multicolumn{5}{|c|}{ Panel A: OLS and 2SLS regression results } \\
\hline & \multirow[t]{2}{*}{ OLS } & \multirow[t]{2}{*}{ OLS } & \multicolumn{5}{|c|}{ 2SLS } \\
\hline & & & GSGP & GSPP & $\begin{array}{c}\text { GSGP+ } \\
\text { GSPP }\end{array}$ & GSPP & GSGP \\
\hline Growth & $\begin{array}{c}-0.453 * * * \\
{[-0.10]} \\
(0.191)\end{array}$ & $\begin{array}{c}-0.463 * * * \\
{[-0.11]} \\
(0.237)\end{array}$ & $\begin{array}{c}-2.072 * * * \\
{[-0.47]} \\
(0.568)\end{array}$ & $\begin{array}{c}-1.760 * * * \\
{[-0.40]} \\
(0.491)\end{array}$ & $\begin{array}{c}-1.832 * * * \\
{[-0.42]} \\
(0.450)\end{array}$ & $\begin{array}{c}-1.216^{*} \\
{[-0.28]} \\
(0.626)\end{array}$ & $\begin{array}{c}-3.878^{*} \\
{[-0.88]} \\
(2.309)\end{array}$ \\
\hline GSGP & & & & & & $\begin{array}{l}-1.019 \\
(0.745)\end{array}$ & \\
\hline \multicolumn{2}{|l|}{ GSPP } & & & & & & $\begin{array}{c}4.283 \\
(4.618)\end{array}$ \\
\hline \multirow{2}{*}{\multicolumn{2}{|c|}{ Initial GDP per capita }} & $\begin{array}{c}-0.334 * * * \\
{[-0.70]} \\
(0.021)\end{array}$ & $\begin{array}{c}-0.382 * * * \\
{[-0.71]} \\
(0.026)\end{array}$ & $\begin{array}{c}-0.382 * * * \\
{[-0.71]} \\
(0.026)\end{array}$ & $\begin{array}{c}-0.382 * * * \\
{[-0.71]} \\
(0.029)\end{array}$ & $\begin{array}{c}-0.377 * * * \\
{[-0.70]} \\
(0.026)\end{array}$ & $\begin{array}{c}-0.397 * * * \\
{[-0.74]} \\
(0.039)\end{array}$ \\
\hline & & Hansen chi-square p-values & & & 0.210 & & \\
\hline Observations & 501 & 501 & 501 & 501 & 501 & 501 & 501 \\
\hline Countries & 14 & 14 & 14 & 14 & 14 & 14 & 14 \\
\hline \multirow[t]{2}{*}{$\mathrm{R}^{2}$} & 0.012 & 0.396 & 0.376 & 0.429 & 0.418 & 0.498 & 0.13 \\
\hline & & & \multicolumn{5}{|c|}{ Panel B: First-stage regression results } \\
\hline \multicolumn{2}{|l|}{ GSGP } & & $\begin{array}{c}1.190 * * * \\
(0.322)\end{array}$ & & $\begin{array}{c}0.383 \\
(0.270)\end{array}$ & & $\begin{array}{r}1.190 * * * \\
(0.322)\end{array}$ \\
\hline \multicolumn{2}{|l|}{ GSPP } & & & $\begin{array}{c}2.021 * * * \\
(0.362)\end{array}$ & $\begin{array}{c}1.609 * * * \\
(0.433)\end{array}$ & $\begin{array}{c}2.021 * * * \\
(0.362)\end{array}$ & \\
\hline \multicolumn{2}{|l|}{ Initial GDP per capita } & & $\begin{array}{l}-0.006 \\
(0.005)\end{array}$ & $\begin{array}{l}-0.007 \\
(0.004)\end{array}$ & $\begin{array}{c}-0.0073 \\
(0.004)\end{array}$ & $\begin{array}{l}-0.007 \\
(0.004)\end{array}$ & $\begin{array}{l}-0.006 \\
(0.005)\end{array}$ \\
\hline \multicolumn{3}{|c|}{ First-stage F-stat (excluded IV) } & 13.7 & 31.0 & 27.0 & 31.0 & 13.7 \\
\hline \multicolumn{3}{|c|}{ First-stage partial $\mathrm{R}^{2}$} & 0.072 & 0.096 & 0.100 & 0.096 & 0.072 \\
\hline \multicolumn{3}{|l|}{ First-stage $\mathrm{R}^{2}$} & 0.072 & 0.097 & 0.102 & 0.097 & 0.072 \\
\hline
\end{tabular}

Notes: Growth is instrumented using the following: growth spillover through geographical proximity (GSPP) and growth spillover through genetic proximity (GSGP). Robust standard errors are presented in round brackets. In columns (3)-(7), the statistics are robust to heteroskedasticity and autocorrelation (kernel = Bartlett; bandwidth $=3$ ). We use $* * *, * *$ and $*$ to refer $1 \%, 5 \%$ and $10 \%$ significance levels, respectively. The constants are not reported for the regressions. The beta coefficients are reported in square brackets. 
Table 3

Robustness checks using alternative measures of top income shares.

\begin{tabular}{|c|c|c|c|c|c|c|}
\hline & $\begin{array}{c}(1) \\
\text { Top } 10 \%\end{array}$ & $\begin{array}{l}\text { (2) } \\
\text { Top 5\% }\end{array}$ & $\begin{array}{c}\text { (3) } \\
\text { Top } 0.5 \%\end{array}$ & $\begin{array}{c}(4) \\
\text { Top } 0.1 \%\end{array}$ & $\begin{array}{c}5) \\
\text { European } \\
\text { countries }\end{array}$ & $\begin{array}{c}(6) \\
\text { Non-Nordic } \\
\text { Countries }\end{array}$ \\
\hline & \multicolumn{6}{|c|}{ Panel A: 2SLS results } \\
\hline \multirow[t]{3}{*}{ Growth } & $-0.887 * * *$ & $-1.158 * * *$ & $-2.609 * * *$ & $-3.842 * * *$ & $-1.469 * * *$ & $-1.832 * * *$ \\
\hline & {$[-0.48]$} & {$[-0.48]$} & {$[-0.52]$} & {$[-0.58]$} & {$[-0.29]$} & {$[-0.51]$} \\
\hline & $(0.481)$ & $(0.447)$ & $(0.524)$ & $(0.575)$ & $(0.537)$ & $(0.493)$ \\
\hline \multirow[t]{2}{*}{ Initial GDP per capita } & $-0.136^{* * *}$ & $-0.204 * * *$ & $-0.433 * * *$ & $-0.559 * * *$ & $-0.440^{* * * *}$ & $-0.323^{* * *} *$ \\
\hline & $(0.524)$ & $(0.631)$ & $(0.674)$ & $(0.639)$ & $(0.031)$ & $(0.032)$ \\
\hline Observations & 421 & 469 & 425 & 432 & 324 & 357 \\
\hline Number of countries & 14 & 14 & 13 & 13 & 9 & 10 \\
\hline $\mathrm{R}^{2}$ & 0.123 & 0.304 & 0.258 & 0.180 & 0.570 & 0.247 \\
\hline \multirow[t]{2}{*}{ Hansen chi-square p-values } & 0.746 & 0.710 & 0.383 & 0.332 & 0.565 & 0.773 \\
\hline & \multicolumn{6}{|c|}{ Panel B: First-stage results } \\
\hline \multirow[t]{2}{*}{ GSGP } & 0.495 & 0.435 & 0.454 & 0.463 & 0.547 & 0.628 \\
\hline & $(0.313)$ & $(0.289)$ & $(0.259)$ & $(0.301)$ & $(0.333)$ & $(0.757)$ \\
\hline \multirow[t]{2}{*}{ GSPP } & $1.542 * * *$ & $1.523 * * *$ & $1.624 * * *$ & $1.517 * * *$ & $1.310^{* * * *}$ & $1.649 * * *$ \\
\hline & $(0.489)$ & $(0.456)$ & $(0.520)$ & $(0.482)$ & $(0.490)$ & $(0.840)$ \\
\hline \multirow[t]{2}{*}{ Initial GDP per capita } & $-0.012 *$ & -0.008 & $-0.009^{*}$ & $-0.009^{*}$ & -0.007 & -0.010 \\
\hline & $(0.007)$ & $(0.005)$ & $(0.005)$ & $(0.005)$ & $(0.005)$ & $(0.006)$ \\
\hline $\begin{array}{l}\text { First-stage F-stat (excluded } \\
\text { IV) }\end{array}$ & 13.2 & 13.7 & 11.8 & 12.7 & 11.1 & 12.7 \\
\hline $\begin{array}{l}\text { First-stage partial } R^{2} \text { (excluded } \\
\text { IV) }\end{array}$ & 0.100 & 0.094 & 0.095 & 0.095 & 0.128 & 0.109 \\
\hline First-stage $\mathrm{R}^{2}$ & 0.102 & 0.095 & 0.097 & 0.095 & 0.127 & 0.109 \\
\hline
\end{tabular}

Notes: Growth is instrumented using the following: growth spillover through geographical proximity (GSPP) and growth spillover through genetic proximity (GSGP). Robust standard errors are presented in round brackets. The statistics are robust to heteroskedasticity and autocorrelation (kernel $=$ Bartlett; bandwidth $=3$ ). We use $* * *, * *$ and * to refer $1 \%, 5 \%$ and $10 \%$ significance levels, respectively. The constants are not reported for the regressions. The beta coefficients are reported in square brackets. 


\section{Table 4}

The effect of growth on the top $1 \%$ income shares-further analysis.

\begin{tabular}{|c|c|c|c|c|c|c|c|c|c|}
\hline Dep. Var.: Top $1 \%$ & (1) & (2) & (3) & (4) & (5) & (6) & (7) & (8) & (9) \\
\hline GDP per capita growth & $\begin{array}{c}-1.816^{* * *} \\
{[-\mathbf{0 . 4 1}]} \\
(0.447)\end{array}$ & $\begin{array}{c}-1.832 * * * \\
{[-\mathbf{0 . 4 2}]} \\
(0.446)\end{array}$ & $\begin{array}{c}-1.599 * * * \\
{[-\mathbf{0 . 3 6}]} \\
(0.425)\end{array}$ & $\begin{array}{c}-1.887 * * * \\
{[-\mathbf{0 . 4 6}]} \\
(0.475)\end{array}$ & $\begin{array}{c}-1.926 * * * \\
{[-\mathbf{0 . 4 1}]} \\
(0.644)\end{array}$ & $\begin{array}{c}-1.871 * * * \\
{[-\mathbf{0 . 4 2}]} \\
(0.432)\end{array}$ & $\begin{array}{c}-2.951 * * * \\
{[-\mathbf{0 . 6 6}]} \\
(0.739)\end{array}$ & $\begin{array}{c}-1.712 * * * \\
{[-\mathbf{0 . 3 6}]} \\
(0.651)\end{array}$ & $\begin{array}{c}-1.824 * * * \\
{[-\mathbf{0 . 4 1}]} \\
(0.587)\end{array}$ \\
\hline Educational attainment & $\begin{array}{c}0.022 \\
(0.022)\end{array}$ & & & & & & & $\begin{array}{c}0.011 \\
(0.027)\end{array}$ & $\begin{array}{c}0.009 \\
(0.030)\end{array}$ \\
\hline Import & & $\begin{array}{c}0.791 * * \\
(0.335)\end{array}$ & & & & & & $\begin{array}{c}0.594 \\
(0.497)\end{array}$ & $\begin{array}{c}1.673 * * * \\
(0.600)\end{array}$ \\
\hline Total investment & & & $\begin{array}{c}-1.336 * * \\
(0.604)\end{array}$ & & & & & $\begin{array}{c}-1.440 * * \\
(0.670)\end{array}$ & $\begin{array}{c}-1.392 * * \\
(0.686)\end{array}$ \\
\hline Patent applications & & & & $\begin{array}{c}0.037 \\
(0.050)\end{array}$ & & & & $\begin{array}{c}0.062 \\
(0.0520\end{array}$ & $\begin{array}{c}0.203 * * * \\
(0.059)\end{array}$ \\
\hline Bank assets & & & & & $\begin{array}{c}0.166 * * * \\
(0.0600\end{array}$ & & & $\begin{array}{l}0.154 * * \\
(0.064)\end{array}$ & $\begin{array}{l}0.157 * * \\
(0.067)\end{array}$ \\
\hline Capital share in income & & & & & & $\begin{array}{c}0.719 * * * \\
{[\mathbf{0 . 2 4}]} \\
(0.245)\end{array}$ & & & $\begin{array}{c}1.020 * * \\
{[\mathbf{0 . 3 7}]} \\
(0.431)\end{array}$ \\
\hline Top marginal tax rates & & & & & & & $\begin{array}{c}-0.479 * * * \\
{[-\mathbf{0 . 2 7}]} \\
(0.184)\end{array}$ & & $\begin{array}{c}-0.553 * * * \\
{[-\mathbf{0 . 2 4}]} \\
(0.122)\end{array}$ \\
\hline Initial GDP per capita & $\begin{array}{c}-0.439 * * * \\
{[-\mathbf{0 . 8 1}]} \\
(0.070)\end{array}$ & $\begin{array}{c}-0.398 * * * \\
{[-\mathbf{0 . 7 4}]} \\
(0.030)\end{array}$ & $\begin{array}{c}-0.346 * * * \\
{[-\mathbf{0 . 6 4}]} \\
(0.033)\end{array}$ & $\begin{array}{c}-0.394 * * * \\
{[-\mathbf{0 . 7 2}]} \\
(0.040)\end{array}$ & $\begin{array}{c}-0.400 * * * \\
{[-\mathbf{0 . 7 4}]} \\
(0.038)\end{array}$ & $\begin{array}{c}-0.357 * * * \\
{[-\mathbf{0 . 6 6}]} \\
(0.030)\end{array}$ & $\begin{array}{c}-0.387 * * * \\
{[-\mathbf{0 . 6 7}]} \\
(0.043)\end{array}$ & $\begin{array}{c}-0.431 * * * \\
{[-\mathbf{0 . 8 0}]} \\
(0.079)\end{array}$ & $\begin{array}{c}-0.484 * * * \\
{[-\mathbf{0 . 8 6}]} \\
(0.100)\end{array}$ \\
\hline Observations & 501 & 501 & 501 & 417 & 367 & 490 & 307 & 367 & 237 \\
\hline R-squared & 0.423 & 0.431 & 0.48 & 0.355 & 0.395 & 0.426 & 0.198 & 0.479 & 0.624 \\
\hline Countries & 14 & 14 & 14 & 12 & 12 & 14 & 10 & 12 & 9 \\
\hline $\begin{array}{l}\text { Hansen chi-square p- } \\
\text { value }\end{array}$ & 0.182 & 0.237 & 0.381 & 0.172 & 0.309 & 0.306 & 0.178 & 0.508 & 0.806 \\
\hline First-stage F-stat & 17.04 & 15.8 & 16.01 & 13.7 & 11.9 & 16.5 & 11.10 & 10.13 & 6.14 \\
\hline First-stage $\mathrm{R}^{2}$ & 0.1205 & 0.1016 & 0.129 & 0.116 & 0.079 & 0.109 & 0.0796 & 0.196 & 0.258 \\
\hline First-stage partial $\mathrm{R}^{2}$ & 0.104 & 0.100 & 0.113 & 0.103 & 0.067 & 0.102 & 0.066 & 0.071 & 0.101 \\
\hline
\end{tabular}

Notes: Except the top 1\% income shares, GDP per capita growth, top marginal tax rates and capital share in GDP, all the other variables are in logarithms. Growth is instrumented using the following: growth spillover through geographical distance (GSPP) and growth spillover through genetic distance (GSGP). Robust standard errors are in round brackets. The statistics are robust to heteroskedasticity and autocorrelation (kernel $=$ Bartlett; bandwidth $=3$ ). $* * *, * *$ and $*$ refer to $1 \%, 5 \%$ and $10 \%$ significance levels, respectively. The coefficients of the constant are not reported for brevity. Beta coefficients are presented in square brackets. First-stage results are not reported except for the F-statistics and $\mathrm{R}^{2} \mathrm{~s}$. 


\section{Table 5}

Testing the non-linearity between growth and top income shares.

\begin{tabular}{|c|c|c|c|c|c|}
\hline & (1) & (3) & (4) & (5) & (6) \\
\hline & Top $1 \%$ & Top $10 \%$ & Top 5\% & Top $0.5 \%$ & Top $0.1 \%$ \\
\hline Growth per capita & $\begin{array}{c}-1.867 * * * \\
{[-\mathbf{0 . 4 2}]} \\
(0.536)\end{array}$ & $\begin{array}{c}-0.782 * * \\
{[-\mathbf{0 . 4 2}]} \\
(0.310)\end{array}$ & $\begin{array}{c}-1.212 * * * \\
{[-\mathbf{0 . 4 7}]} \\
(0.371)\end{array}$ & $\begin{array}{c}-2.818 * * * \\
{[-\mathbf{0 . 5 7}]} \\
(0.929)\end{array}$ & $\begin{array}{c}-4.185 * * * \\
{[-\mathbf{0 . 6 3}]} \\
(1.358)\end{array}$ \\
\hline Squared growth per capita & $\begin{array}{l}-7.276 \\
(7.062)\end{array}$ & $\begin{array}{c}0.05 \\
(3.802)\end{array}$ & $\begin{array}{l}-3.907 \\
(4.772)\end{array}$ & $\begin{array}{c}-10.677 \\
(11.41)\end{array}$ & $\begin{array}{c}-17.535 \\
(17.25)\end{array}$ \\
\hline Initial GDP per capita & $\begin{array}{c}-0.427 * * * \\
(0.051)\end{array}$ & $\begin{array}{c}-0.134 * * * \\
(0.049)\end{array}$ & $\begin{array}{c}-0.232 * * * \\
(0.038)\end{array}$ & $\begin{array}{c}-0.517 * * * \\
(0.100)\end{array}$ & $\begin{array}{c}-0.693 * * * \\
(0.146)\end{array}$ \\
\hline Observations & 501 & 421 & 469 & 425 & 432 \\
\hline R-squared & 0.326 & 0.172 & 0.253 & 0.026 & 0.268 \\
\hline Number of Countries & 14 & 14 & 14 & 13 & 13 \\
\hline $\begin{array}{l}\text { Hansen chi-square p- } \\
\text { values }\end{array}$ & 0.063 & 0.054 & 0.098 & 0.064 & 0.045 \\
\hline First-stage F-statistics & 13.4 & 11.38 & 11.8 & 10.97 & 10.9 \\
\hline First-stage partial $\mathrm{R}^{2}$ & 0.103 & 0.103 & 0.096 & 0.099 & 0.097 \\
\hline First-stage $\mathrm{R}^{2}$ & 0.103 & 0.105 & 0.097 & 0.100 & 0.098 \\
\hline
\end{tabular}

Notes: Growth is instrumented using the following: growth spillover through geographical proximity (GSPP), growth spillover through genetic proximity (GSGP) and their squares. Robust standard errors are presented in round brackets. The statistics are robust to heteroskedasticity and autocorrelation (kernel $=$ Bartlett; bandwidth $=3$ ). We use ***, ** and * to refer 1\%, 5\% and $10 \%$ significance levels, respectively. The constants are not reported for any of the regressions. The beta coefficients are reported in square brackets. First-stage results are not reported except for the F-statistics and $\mathrm{R}^{2} \mathrm{~s}$. 


\section{Figures}

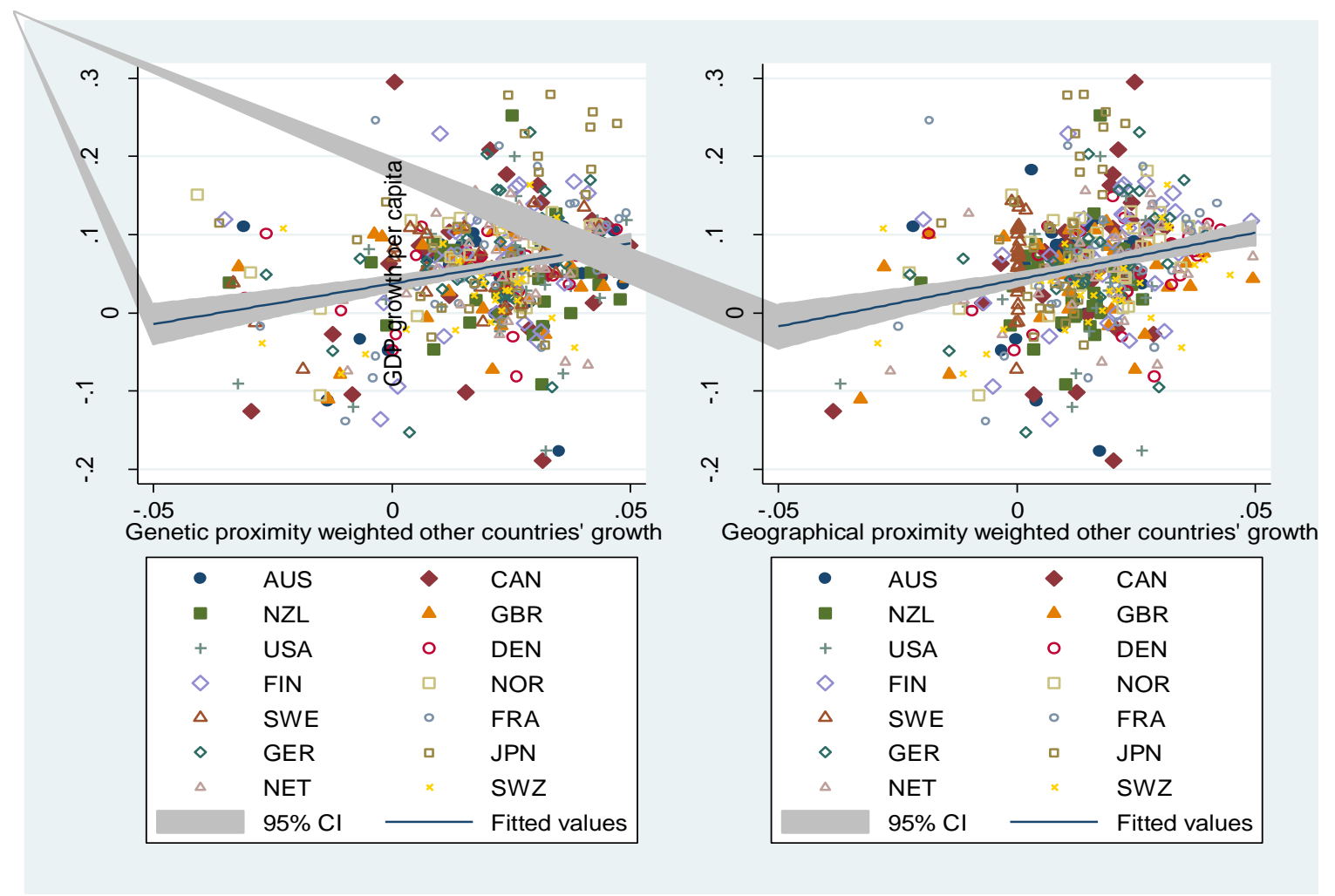

Fig. 1. Economic growth and its two instruments (GSGP and GSPP).
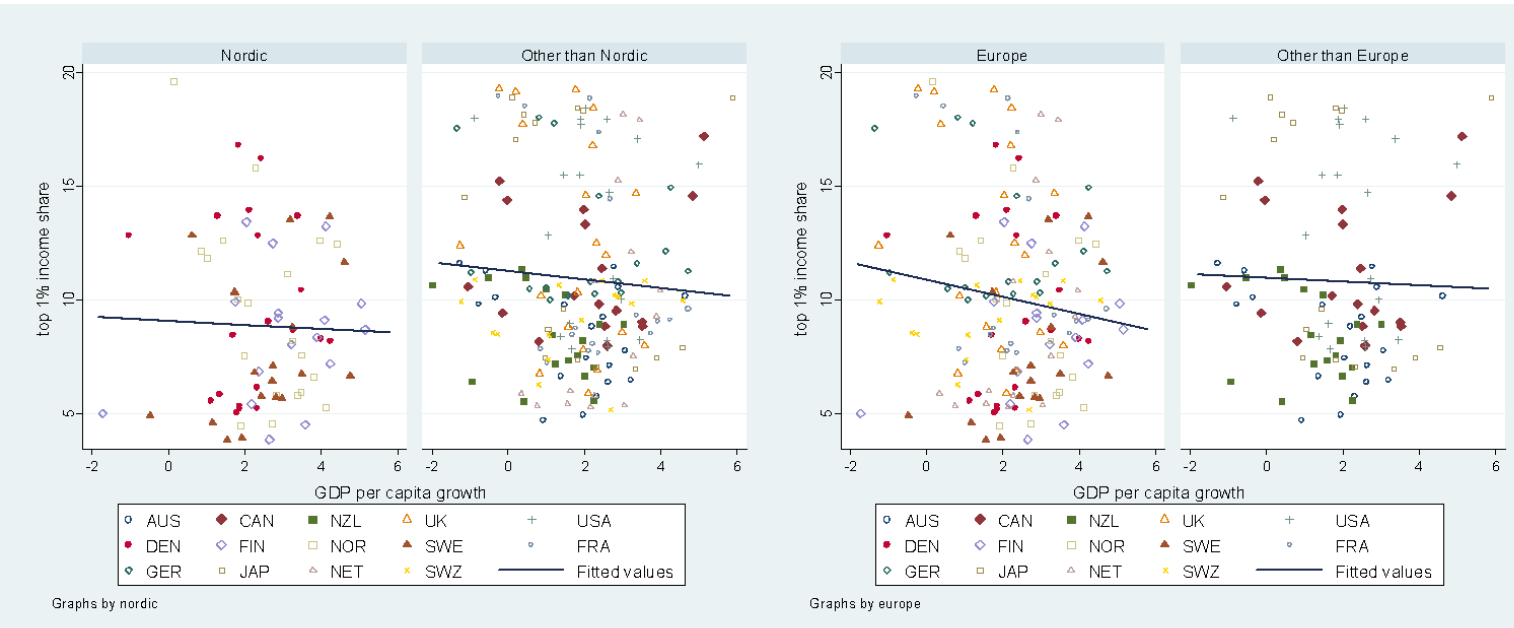

Fig. 2. Economic growth and top $1 \%$ income shares. 


\section{Appendix}

\section{Genetic distance}

Genetic distance is the measure of the difference in allelic frequency between two population groups. It is measured as the probability of finding two different versions of the same gene (alleles) at the locus of a chromosome randomly chosen from two population groups and is expressed as the time elapsed since the two groups had a common ancestor. The connection between the elapsed time and the genetic distance is that the greater the time since the two groups had a common ancestor, the more significant is the difference in allelic frequency. Thus, measuring the difference in allelic frequency provides an impression of how long the two population groups have been apart in terms of sharing common genetic traits. Guiso et al. (2009) argue that two genetically distant groups are dissimilar in traits; however, genetically closer groups share many traits that may induce them to have smooth interactions in terms of trade and other exchanges. In this research, we measure genetic proximity as the inverse of genetic diversity to capture the closeness of two genetic groups.

In reality, a country may comprise a mixture of many genetically diverse groups with different allelic frequencies. Cavalli-Sforza et al. (1996) identify 42 main genetic groups worldwide, with 128 allele versions in 45 gene types. Each genetic group has a very high level of genetic similarity and is differentiable from the other groups. Spolaore and Wacziarg (2009) compile the genetic distance data of country pairs, in which each country's allelic frequency is constructed using the weighted average allelic frequency of ethnic groups. The population fractions of the groups are used as weights in the calculation.

Note that different alleles may or may not provide observable phenotypic traits, such as eye colour and skin colour. If they do not provide observable phenotypic traits, they are called selectively neutral alleles. With few exceptions, most alleles are selectively neutral. Genetic 
distance is measured based on only selectively neutral alleles, which change over long periods without producing any observable phenotypic traits. Therefore, starting from the same ancestor, selectively neutral alleles proportionally change over time. The more elapsed time, the two groups diverge more from each other in terms of their shared genetic traits. This provides the opportunity to compare various socio-economic and health outcomes.

Genetic proximity and cultural proximity are intertwined. They co-evolve over time (Richerson \& Boyd, 2005) and pass on to offspring over the generations (Spolaore \& Wacziarg, 2009). Therefore, the elapsed time that measures genetic distance also acts as a proxy measure of cultural distance between two population groups. 


\section{Appendix Tables}

\section{Table A1}

Correlations among the important variables.

\begin{tabular}{lllllllll}
\hline & $(1)$ & $(2)$ & $(3)$ & $(4)$ & $(5)$ & $(6)$ & (7) & (8) \\
\hline (1) Top 1\% & 1.000 & & & & & & & \\
(2) GDP per capita & -0.533 & 1.000 & & & & & & \\
(3) Educational attainment & -0.405 & 0.839 & 1.000 & & & & & \\
(4) Total import & -0.053 & 0.197 & -0.016 & 1.000 & & & & \\
(5) Total investment & -0.358 & 0.169 & 0.247 & -0.114 & 1.000 & & & \\
(6) Domestic patent applications & 0.147 & 0.210 & 0.197 & -0.478 & 0.053 & 1.000 & & \\
(7) Bank assets & -0.051 & 0.432 & 0.347 & -0.062 & 0.143 & 0.437 & 1.000 & \\
(8) Capital share in GDP (\%) & 0.103 & -0.511 & -0.443 & -0.043 & 0.392 & -0.019 & 0.014 & 1.000 \\
(9) Top marginal tax rates & -0.468 & 0.123 & 0.100 & -0.031 & 0.152 & -0.042 & -0.166 & 0.018 \\
\hline (1) Top 1\% & 1.000 & & & & & & & \\
(2) Top 10\% & 0.913 & 1.000 & & & & & & \\
(3) Top 5\% & 0.952 & 0.968 & 1.000 & & & & & \\
(4) Top 0.5\% & 0.997 & 0.893 & 0.936 & 1.000 & & & & \\
(5) Top 0.1\% & 0.982 & 0.854 & 0.905 & 0.991 & 1.000 & & & \\
(6) GSGP (one-year lag) & -0.218 & -0.203 & -0.202 & -0.223 & -0.232 & 1.000 & & \\
(7) GSPP (one-year lag) & -0.135 & -0.146 & -0.135 & -0.137 & -0.137 & 0.648 & 1.000 & \\
(8) GDP per capita growth & -0.109 & -0.091 & -0.101 & -0.118 & -0.125 & 0.269 & 0.263 & 1.000 \\
\hline
\end{tabular}

Note: Three-year average data since 1900 are used. In the case of GSGP and GSPP, yearly data has been constructed first; the three-year average is then calculated accordingly. Total import and total investment are presented as a fraction of GDP. All top income shares data are in natural logarithm. 


\section{Table A2}

Summary statistics of the variables.

\begin{tabular}{|l|c|c|c|c|c|}
\hline Variables & $(1)$ & $(2)$ & $(3)$ & $(4)$ & $(5)$ \\
\hline & Obs & Mean & Std. dev. & Min & Max \\
\hline Per capita GDP growth rate (\%) & 504 & 0.058 & 0.090 & -0.659 & 0.433 \\
\hline Initial GDP per capita (logs) & 504 & 8.940 & 0.739 & 7.066 & 10.349 \\
\hline Educational attainment (years) & 518 & 8.893 & 2.530 & 0.811 & 15.249 \\
\hline Import & 518 & 0.170 & 0.091 & 0.009 & 0.575 \\
\hline Total investment & 518 & 0.178 & 0.063 & 0.028 & 0.721 \\
\hline & & & & & \\
\hline Patent application domestic (logs) & 432 & 8.679 & 1.588 & 4.666 & 12.833 \\
\hline Bank assets (ln) & 380 & -0.755 & 0.493 & -2.112 & 0.296 \\
\hline Capital share in income (\%) & 506 & 0.511 & 0.136 & 0.083 & 0.958 \\
\hline Top marginal tax rates & 310 & 0.466 & 0.228 & 0.020 & 0.975 \\
\hline Top 1\% income share & 514 & 2.322 & 0.404 & 1.299 & 3.295 \\
\hline Top 10\% income share & 428 & 3.522 & 0.174 & 3.106 & 3.96 \\
\hline Top 5\% income share & 479 & 3.149 & 0.240 & 2.582 & 3.761 \\
\hline Top 0.5\% income share & 434 & 1.947 & 0.468 & 0.882 & 3.063 \\
\hline Top 0.1\% income share & 441 & 1.139 & 0.626 & -0.249 & 2.534 \\
\hline & & & & & \\
\hline GSGP (one-year lag) & 504 & 0.022 & 0.020 & -0.104 & 0.189 \\
\hline GSPP (one-year lag) & 504 & 0.0151 & 0.015 & -0.038 & 0.071 \\
\hline
\end{tabular}

Note: Three-year average data since 1900 are used. In the case of GSGP and GSPP, yearly data has been constructed first; the three-year average is then calculated accordingly. Total import and total investment are presented as a fraction of GDP. All top income shares data are in natural logarithm. 